Article

\title{
Green Marketing as a Part of the Socially Responsible Brand's Communication from the Aspect of Generational Stratification
}

\author{
Margareta Nadanyiova * ${ }^{\mathbb{D}}$, Lubica Gajanova $\unrhd$ and Jana Majerova \\ Department of Economics, Faculty of Operation and Economics of Transport and Communications, \\ University of Zilina, Univerzitna 1, 01026 Žilina, Slovakia; lubica.gajanova@fpedas.uniza.sk (L.G.); \\ jana.majerova@fpedas.uniza.sk (J.M.) \\ * Correspondence: margareta.nadanyiova@fpedas.uniza.sk; Tel.: +421-41-513-3205
}

Received: 1 July 2020; Accepted: 28 August 2020; Published: 31 August 2020

\begin{abstract}
Green marketing is focused on a responsible approach to the environment, which is integrated into various areas of society. In order to build a successful and socially responsible brand, it strives to apply environmental principles that attract new customers or strengthen the loyalty of existing ones. To ensure success, it is necessary to focus on green marketing as a part of socially responsible brands' communication to individual target groups, which can be divided according to the age of the consumer generations, which have similar requirements for product characteristics. The main aim of the paper is to determine the differences between generational cohorts of Slovak consumers in perception of green marketing as part of socially responsible brands' communication. The most important sources for secondary data were scientific research, statistical databases, and published professional publications. In order to find out the perception of green marketing as a part of socially responsible brands' communication from the aspect of generational stratification, a questionnaire survey was conducted among Slovak consumers. Based on the analysis and results of the questionnaire survey, benefits of green marketing as part of socially responsible brands' communication focused on individual consumers' generations are highlighted, such as gaining competitive advantage, increasing the brand value, improving brand loyalty, and increasing the attractiveness for investors.
\end{abstract}

Keywords: green marketing; corporate social responsibility; socially responsible brand; marketing communication; generational stratification; consumer generations; sustainability

\section{Introduction}

Currently, the primary economic goal of the company can be defined as the creation of value and its maximization, including profit maximization [1]. In order to achieve its goal, a company interacts with the surrounding economic, political, environmental, technological, and social environment. It follows from the above that each company thus creates a certain impact on its business environment, both positive and negative. Therefore, it is essential that the company is aware of its impact and tries to regulate it to the maximum benefit of the whole society. In this case, the company, and thus the company's brand, can be labelled as socially responsible.

The natural environment is the part of the company's marketing environment, and therefore its protection should be necessarily an integral part of the company's marketing strategy. Green marketing as a concept based on corporate social responsibility represents an environmentally oriented and responsible marketing approach, the application of which is constantly gaining momentum in almost all developed and developing countries [2-4]. It is an important subject of academic research, the essence 
of which lies in the effort to address the social dimension of marketing in terms of drawing on environmental resources, the social and environmental impact of current marketing, and greening various aspects of traditional marketing. It is one of the new forms of marketing that can play a very important role in providing opportunities for the well-being of society [5-8].

Nowadays, there is no universal definition of green marketing. There is also some freedom in using this term. It can be replaced with terms such as "environmental", "ecological", or "eco-marketing". McDaniel and Rylander use this term for consumer and environmental marketing strategies [9]. Baker defines green marketing as a holistic management process responsible for identifying, anticipating, and meeting the needs of consumers and society in an efficient and sustainable way [10]. According to Juraskova, green marketing focuses on all activities aimed at satisfying human needs or desires but with minimal impact on the natural environment [11]. Similarly, Polonsky claims that the concept of green marketing includes all activities carried out in order to implement and facilitate any changes aimed at satisfying human needs and desires with minimal harmful impact on the environment [6]. The American Marketing Association defines green marketing in several ways-from the point of sale, socio-marketing, as well as environmental [12,13]. Grant points out that the responsibility for environmental protection lies not only with the government, large corporations, and nongovernmental organizations, but with the responsibility of the whole society, and seeks to incorporate green behavior into the normal life of every consumer. He characterizes green marketing as a set of five features called "5 I": intuitive, integrative, innovative, inviting, and informed [14].

The key factor of the socially responsible brand's success is its appropriate communication with target groups. Without efficient and properly targeted communication of socially responsible activities, the brand cannot achieve its goals $[15,16]$. Green marketing as a part of socially responsible communication can positively influence the attitudes of individual target groups towards the brand. Therefore, it is necessary to focus the communication on individual target groups, which can be divided according to the age of the consumers' generations. The decision-making process during buying behavior of the consumers of a particular generation may often have the same characters, expecting similar requirements for product characteristics [17]. According to Howe and Strauss, who have long dealt with consumer generations and their importance in society, members of a consumers' generation change their attitudes and behavior with age, but at the same time, people of the same age do not have the same attitudes and behavior across different generations. The very concept of a generation is derived from the combination of the memories, slang language used, habits, life experiences, and recognized values of individual generation members [18]. According to Tolbize, a generation is an easily identifiable group of people who are identical in terms of their year of birth, age, location, and significant life events [19]. Similarly, Troll defines the term generation on the basis of the internal structure of different groups and perceives generation through its content side, i.e., perceiving basic cultural differences or differences in lifestyles [20].

In this context, many academics have focused their research on the issue of generational changes [21-23]. Thus, we can claim that it can be considered as the main driving force of society and changes in different fields such as politics, culture, economics, and so forth, including the advent of new communication technologies and their impact on changing the individual attitudes and behavior of consumers. Gradual changes in society are thus represented by new generations, which are born into a new environment, behave differently, and at the same time transform this new environment according their image.

Due to the main aim of the paper, that is, to determine the perception of the green marketing as a part of the socially responsible brand's communication from the aspect of generational stratification, it is necessary to analyse the characteristics of behavior of individual consumers' generations.

From a terminological point of view, the first defined generation was the so-called Baby Boomers, named in the 1960s by the US Federal Agency Census Bureau [24,25]. Later, other generations were identified, called the GI generation, Silent Generation, Baby Boomers, Generation X, Millennials, and Generation Z [26], respectively, or the Depression Generation, World War II, Post War cohort, 
Boomers I (i.e., Baby Boomers), Boomers II (i.e., Jones Generation), Generation X, Generation Y (so called Echo Boomers or Millennials), and Generation Z [27]. With regard to the last generation, there is a terminological controversy related to the ongoing search for a suitable label. In the professional literature, we refer to terms such as Generation Z, iGen, Post-Millennials, or the Generation of patriots [28] to denote the same generation. This situation reduces the clarity of the professional literature and represents an internal barrier to a comprehensive research of this generation and its marketing implications. However, another negative phenomenon is not only the mentioned terminological inconsistency, but also the variability of dating of individual identified generations. The youngest of the generations identified so far is referred to as the so-called Generation Alpha [29].

The variability in the labelling of individual generations forming a barrier to complex generational stratification is summarized in Table 1. The most significant problem is in the case of Millennials.

Table 1. The distribution of consumer generations by various authors [25].

\begin{tabular}{ccccc}
\hline Source & \multicolumn{2}{c}{ Distribution of Consumer Generations } \\
\hline $\begin{array}{c}\text { Howe \& Strauss } \\
(2000)\end{array}$ & $\begin{array}{c}\text { Silent Generation } \\
(1925-1943)\end{array}$ & $\begin{array}{c}\text { Boom } \\
\text { Generation } \\
(1943-1960)\end{array}$ & $\begin{array}{c}\text { 13th Generation } \\
(1961-1981)\end{array}$ & $\begin{array}{c}\text { Millennial Generation } \\
(1982-2000)\end{array}$ \\
\hline $\begin{array}{c}\text { Lancaster \& Stillman } \\
(2002)\end{array}$ & $\begin{array}{c}\text { Traditionalists } \\
(1900-1945)\end{array}$ & $\begin{array}{c}\text { Baby Boomers } \\
(1946-1964)\end{array}$ & $\begin{array}{c}\text { Generation Xers } \\
(1965-1980)\end{array}$ & $\begin{array}{c}\text { Millennial Generation; } \\
\text { Echo boomers; Generation Y; } \\
\text { Baby Busters; Generation Next } \\
(1981-1999)\end{array}$ \\
\hline $\begin{array}{c}\text { Martin \& Tulgan } \\
(2002)\end{array}$ & $\begin{array}{c}\text { Silent Generation } \\
(1925-1942)\end{array}$ & $\begin{array}{c}\text { Baby Boomers } \\
(1946-1960)\end{array}$ & $\begin{array}{c}\text { Generation X } \\
(1965-1977)\end{array}$ & $\begin{array}{c}\text { Millennials } \\
(1978-2000)\end{array}$ \\
\hline $\begin{array}{c}\text { Oblinger \& Oblinger } \\
(2005)\end{array}$ & $\begin{array}{c}\text { Matures } \\
(<1946)\end{array}$ & $\begin{array}{c}\text { Baby boomers } \\
(1947-1964)\end{array}$ & $\begin{array}{c}\text { Gen-Xers } \\
(1965-1980)\end{array}$ & $\begin{array}{c}\text { Gen-Y; } \\
\text { NetGen; Millennials } \\
(1981-1995)\end{array}$ \\
\hline $\begin{array}{c}\text { Tapscott } \\
(1998)\end{array}$ & - & $\begin{array}{c}\text { Baby boomers } \\
(1946-1964)\end{array}$ & $\begin{array}{c}\text { Generation X } \\
(1965-1975)\end{array}$ & $\begin{array}{c}\text { Digital Generation } \\
(1976-2000)\end{array}$ \\
\hline $\begin{array}{c}\text { Zemke et al. } \\
(2000)\end{array}$ & $\begin{array}{c}\text { Veterans } \\
(1922-1943)\end{array}$ & $\begin{array}{c}\text { Baby boomers } \\
(1943-1960)\end{array}$ & $\begin{array}{c}\text { Gen-Xers } \\
(1960-1980)\end{array}$ & $\begin{array}{c}\text { Nexters } \\
(1980-1999)\end{array}$ \\
\hline
\end{tabular}

Generational stratification, according to the independent research agency Pew Research Center, which is considered terminologically consensual in the global scientific community, defines the following generations [30]:

- $\quad$ Silent (born 1928-1945)

- Boomers (born 1946-1964)

- Generation X (1965-1980)

- Millennials (born 1981-1996)

- Postmillennials/Generation Z (born 1997-2012)

- Unknown (2012-present) [30].

Such generational stratification, i.e., market segmentation, based on the affiliation of consumers to individual generational cohorts is used to monitor the impact of historical context and socio-cultural changes on population behavior in order to subsequently predict generational stereotypes in the context of purchasing decisions and subjectively perceived sources of value as a precondition for the creation of a loyal consumer base, forming the precondition for the sustainable operation of the company on the market [30]. In addition to marketing implications, generational stratification is increasingly used in other areas of business management, such as human resources [23,31,32].

The applicability of a differentiated approach based on generational stratification is increasingly used in addition to business in other areas, such as education and the military [33]. The importance of monitoring generational differences and their subsequent effective interpretation is thus growing in all sectors. On the other hand, Reeves and on criticize a generational approach based on proclaimed differences across generalized characteristics of generational cohorts due to limited data and the lack of reliability and validity of research to date. They do not deny that differences exist, but emphasize 
the need for more rigorous research before new practices are introduced and before the identified specificities of the generational groups are identified. However, this fact gives space for additional research to examine consumer generations and their behavior in different areas, such as their perception of green marketing in brands strategy [25].

Generational stratification according to McCrindle (used in this article) includes [34]:

1. Baby Boomers (1946-1964) are related to post-war population expansion and represent the most numerous generation among the generations recorded so far.

2. Generation X (1965-1980) is also referred to as the so-called Baby Busters, Post Boomers, or Slackers.

3. Millennials (1981-1996) also known as Generation Y, Generation Next, Digital Generation, Nexters, Echo Boomers, Google Generation, or the Why Generation, is currently the most numerous generation [35].

4. Post-Millennials (1997-2009) are also referred to as Generation Z, Zeds, Zees, Bubble Wrap Kids, The New Millennials, Digital Natives, Wired Generation, Screenagers, or iGen [36].

Understanding the buying behavior and environmental thinking of consumers from the aspect of generational stratification can help companies explore the target segments of the environmental market and thus improve their green marketing strategy as a part of the socially responsible brand's communication.

There are many scientific papers and surveys aimed at the issue of the perception of green marketing as apart of socially responsible brands' communication from the aspect of generational stratification [37-47]. However, based on the dissonances of Slovak consumers recognized by Kliestikova and Janoskova, it is not possible to copy the pattern from foreign effective practice of brand value building and managing [48].

For the reasons mentioned above, the article is aimed at the determination of the differences between generational cohorts of Slovak consumers in their perception of green marketing as a part of socially responsible brands' communication. To achieve the main goal of the article, analysis of green marketing as a part of socially responsible brands' communication, as well as analysis of the environmental thinking of consumers from the aspect of generational stratification was conducted, and the questionnaire survey was conducted among Slovak consumers. Based on the result of the questionnaire survey and verification of statistical hypotheses, it was found out that the environmental behavior of individual consumer's generations has the same character, and their attitude to socially responsible brands is similar as well. In addition, Millennials and Post-Millennials are determined as a target group of socially responsible brands in Slovak conditions.

In the scope of the above-mentioned, research hypotheses are set:

- Hypothesis 1 (H1). When making purchasing decisions, 50\% of Slovak consumers prefer a brand that behaves ecologically (applies the principles of green marketing).

- Hypothesis 2 (H2). More than 50\% of Baby Boomers consider the application of green marketing as a part of the socially responsible brand's communication to be a factor in increasing brand value.

- Hypothesis 3 (H3). More than 50\% of consumers in Generation X consider the application of green marketing as a part of the socially responsible brand's communication to be a factor in increasing brand value.

- Hypothesis 4 (H4). More than 50\% of Millennials consider the application of green marketing as a part of the socially responsible brand's communication to be a factor in increasing brand value.

- Hypothesis 5 (H5). More than 50\% of Post-Millennials consider the application of green marketing as a part of the socially responsible brand's communication to be a factor in increasing brand value.

- Hypothesis 6 (H6). There is statistically significant dependence between the age of Slovak consumers (membership of a generational cohort) and their perception of a brand's usage of green marketing principles as an important factor in purchasing decisions. 


\section{Materials and Methods}

To find out the topicality of green marketing issues, a bibliometric analysis was performed during April 2020 and presented in the Results section. Bibliometrics is a scientific discipline that deals with the quantitative aspects of the creation, dissemination, and use of recorded information [49]. Bibliometric analysis in this paper was performed in the scientific databases Web of Science and Scopus for the period 2000-2019 using the methods of descriptive statistics and the bibliometric map. A bibliometric map is a spatial presentation of the relationships between scientific disciplines, topics, and individual documents, as well as authors based on some formal quantifiable features of the scientific literature at a given time [50].

In this paper, the bibliometric map identifies key areas of scientific research interest from the Web of Science and Scopus databases based on a content analysis of scientific publications with a focus on green marketing for the period 2000-2019. This means the bibliometric map presents a network visualization (clusters) of keywords of scientific publications on the topic of green marketing. We decided to analyse keywords due to the use of this information in the search for factors related to green marketing, and we chose the occurrence of the area in the map as the criterion for the occurrence of the issue in more than 12 publications. This is a standard way of processing a bibliometric map using the VOS Viewer software platform. The size of the circle represents the weight, and therefore the importance, of the keyword. The colour of the circles determines the cluster to which the keyword belongs. Individual links are links between items. By default, up to 1000 of the strongest links can be displayed. The distance between the circles expresses the relationship of the keywords in terms of correlation links, and the closer they are, the stronger is the relationship between the keywords.

The important sources for secondary data were scientific research, statistical databases, published professional publications used in literature review, analyses of generational cohorts, their environmental behavior, and so forth. In order to find out the perception of green marketing as a part of the socially responsible brand's communication from the aspect of generational stratification, a questionnaire survey was conducted among Slovak consumers.

The questionnaire survey was aimed at finding out the perception of green marketing as a part of the socially responsible brand's communication from the aspect of generational stratification. To determine the sample size, the base file representing number of population older than 15 was obtained from demographic statistics of the Statistical Office of the Slovak Republic. The selection of the respondents in the sample set took place at random and, as mentioned, was based on the number of Slovak inhabitants older than $15(4,594,153)$ because of their legal working subjectivity. Thus, the main presumption of autonomous buying decision-making has been fulfilled. The confidence interval $5 \%$ was determined, and confidence level $95 \%$; thus, the error rate $5 \%$ was admitted. The sample size of 384 respondents was calculated. The actual number of respondents who participated in the questionnaire survey was 2035 , so the minimum sample size was met.

The questionnaire consists of three parts. The first part covered the general socio-demographic profile of respondents. The second part was focused on the environmental behavior of respondents. The last part dealt with the perception of green marketing as a part of the socially responsible brand's communication. The time required for the survey was 2 months (January-February 2020). The survey took the form of computer-assisted web interviewing, respecting the ICC/ESOMAR (International code on Market, Opinion and Social Research and Data Analytics). For the processing of the survey data, the quantitative assessment method was applied.

General scientific methods (i.e., excerption, description, comparative analysis, deduction, and induction) were used for data processing, as well as mathematical and statistical methods in the evaluation of data from the survey using IBM SPSS Statistics software.

In order to achieve the main goal of the paper, based on the theoretical background and survey results, research hypotheses were formulated in the Introduction. Hypothesis 1 is focused on verifying whether the majority of Slovak consumers generally prefer brands that behave ecologically. The formulation of hypotheses $2-5$ is based on the effort to determine the perception of green marketing 
as a part of the socially responsible brand's communication as a factor in increasing brand value from the perspective of individual generational cohorts. The goal is to find target groups for communication of the socially responsible brands. Hypothesis 6 is focused on investigating the statistical dependence between the age of Slovak consumers and their perception of the brand's usage of green marketing principles as an important factor in purchasing decisions. The marginal rate $50 \%$ used in hypotheses was set as the expression of the simple majority [51].

For our research, we chose the method of statistical hypothesis testing, because it is one of the most important statistical inference procedures. Statistical hypotheses testing is defined as a statement of the assumption of unknown parameters in the basic set, which is formulated as a statistical hypothesis, and its validity is verified by statistical procedures based on selection characteristics. The role of statistical hypothesis testing is to decide whether to accept or reject the hypothesis regarding the basic set in accordance to the information from the available choice. In verification of the hypotheses, the methodology of statistical hypothesis testing consisting of the following steps was met [52].

The test statistic for hypotheses $1-5$ was calculated by using the method of testing a single proportion by one-tailed testing, because it is commonly used [53,54].

In the case of hypothesis 6, we used Pearson's Chi-square test of independence to determine whether there is a statistically significant relationship between the age of Slovak consumers (membership of a generational cohort) and their perception of the brand's usage of green marketing principles as an important factor in purchasing decisions. For the purpose of determining the dependence, we made a contingency table, where the frequencies are arranged depending on both characters. Finally, we measured the intensity of the association dependence between the variables by the Cramer's V [54,55].

As the dependence between the variables was confirmed, it was justified to examine the internal relationships between the characters using the correspondence analysis in the IBM SPSS Statistics software. The correspondence analysis is a technique suitable for analysing data in two or more dimensional contingency tables. Its advantage is a clear visualization of the links between the categories of variables. The correspondence analysis can also be seen as a parallel methodology to factor analysis of numerical data in cases where frequencies in the fields of a contingency table or a set of contingency tables enter into the analysis. However, it is only a descriptive and exploratory method, so it has to be preceded by testing the hypothesis on the independence of observed characters in a contingency table, which can be tested, e.g., using the Chi-square test. The correspondence analysis is based on the transformation of points of the multidimensional space representing the examined categories into a space of the lower dimension, mostly in the plane. This transformation is ambiguous and allows a focus on the detection of a certain type of relationship between categories. The quality of the transformation is evaluated on the basis of rates derived from the total inertia. The correspondence analysis has a relatively simple interpretation, most often based on the distance of points in the plane on the so-called correspondence map [56,57].

\section{Results}

Many definitions of green marketing are proof of its scale and up-to-date. The topicality of this issue is declared by the following presented bibliometric analysis focused on the scientific databases Web of Science as well as Scopus and their content of scientific articles and studies with a focus on green marketing.

\subsection{Results of the Bibliometric Analysis}

The results of the descriptive statistics within the bibliographic analysis are displayed in Figure 1, which shows the development of the number of scientific articles and studies from the Web of Science and Scopus databases on green marketing after 2000. As it can be seen from the Figure 1, the interest in green marketing has an upward trend in the scientific and academic community, especially over the last 10 years. 


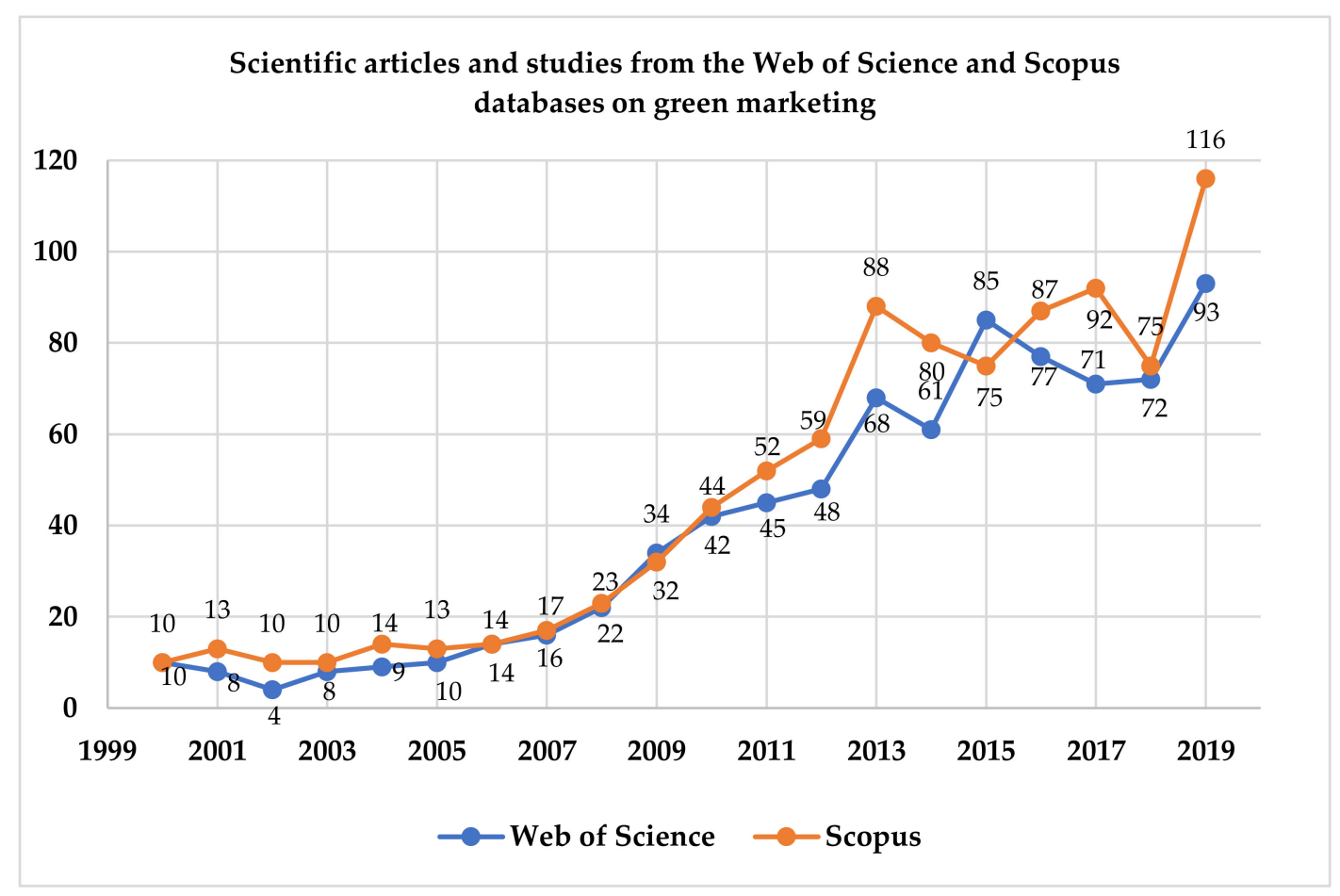

Figure 1. Number of scientific articles and studies from the Web of Science and Scopus databases on the green marketing for the period from 2000 to 2019.

The following bibliometric map (also called the science map) identifies key areas of scientific research interest from the Web of Science and Scopus databases based on a content analysis of scientific publications with a focus on green marketing for the period 2000-2019.

Figure 2 presents a network visualization (clusters) of keywords of scientific articles and studies from the Web of Science database on the topic of green marketing using the VOS Viewer software platform. It follows from Figure 2 that the keywords of scientific publications focused on green marketing can be grouped into five clusters, and the link to concepts such as sustainability, corporate social responsibility, environment, consumer behavior, as well as communication, is also clear.

Figure 3 presents a network visualization (clusters) of keywords of scientific articles and studies from the Scopus database on the topic of green marketing using the VOS Viewer software platform. It follows from Figure 3 that, in contrast to the Web of Science database, the keywords of scientific publications from the Scopus database focused on green marketing can be grouped into seven clusters. Similarly, the link to concepts such as sustainability, corporate social responsibility, environment, consumer behavior, as well as communication, is also clear.

However, we can say that although a number of domestic and foreign authors have dealt with the issue of green marketing as a part of corporate social responsibility, some areas remain unexplored or have been little explored. One of them is the fact that consumers are still unable to appreciate socially responsible brands. The reason may be insufficient information of stakeholders about their green as well as socially responsible activities caused, among other things, by poorly set up and targeted communication. The second area is the perception of green marketing by generational cohorts and their different points of view on socially responsible brands. 


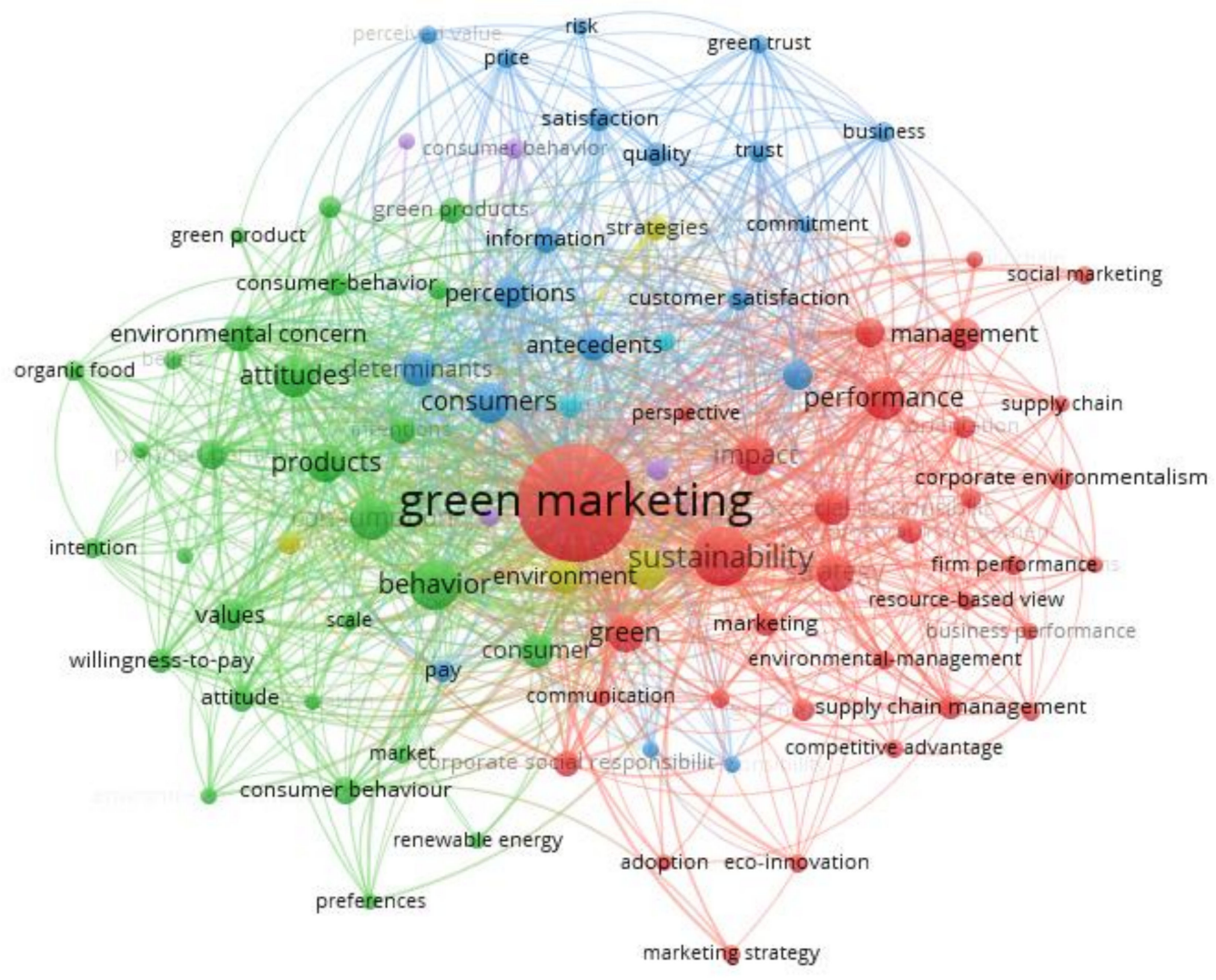

Figure 2. Bibliometric network of keywords for scientific articles and studies from the Web of Science on green marketing.

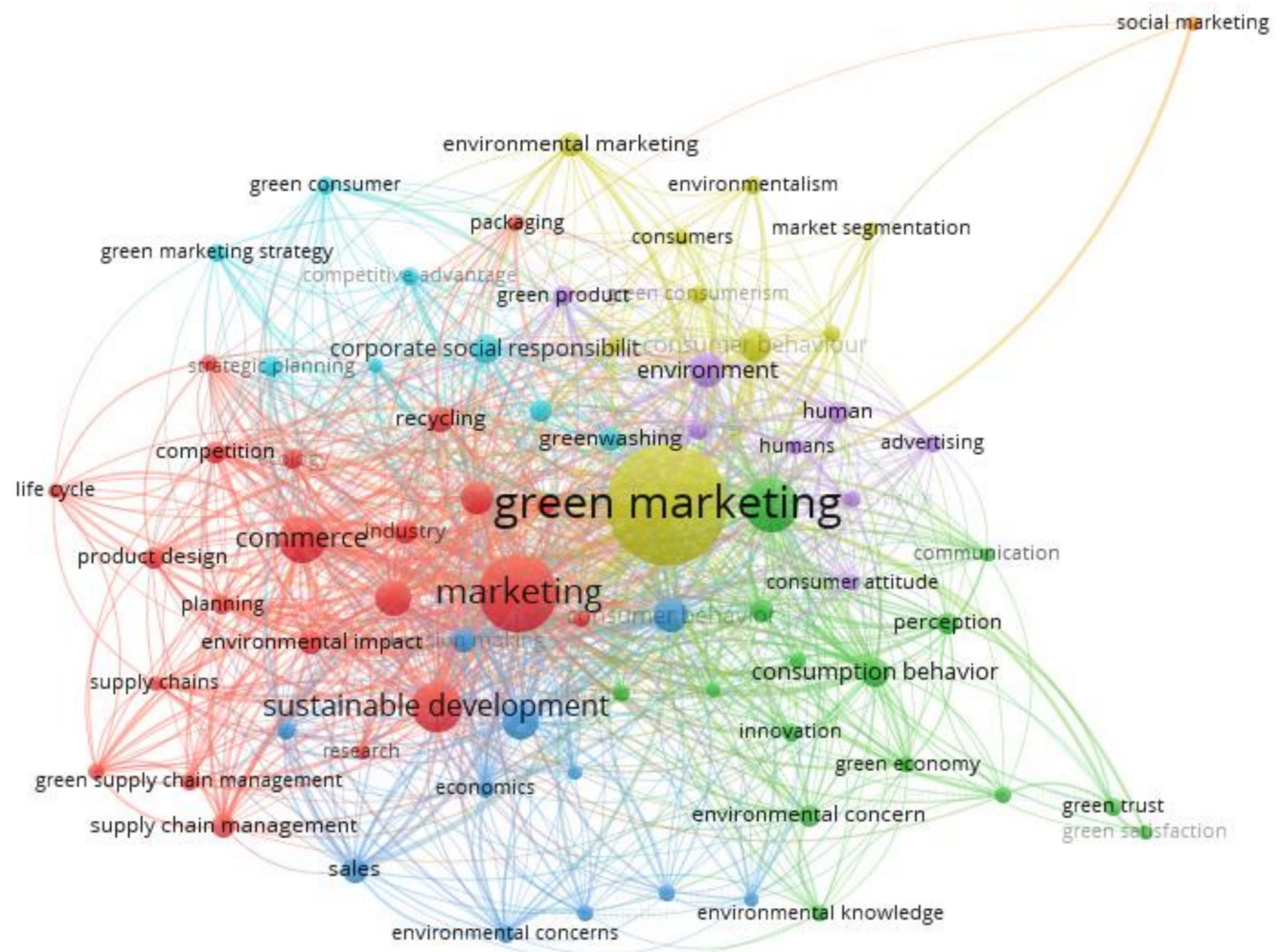

Figure 3. Bibliometric network of keywords for scientific articles and studies from Scopus on green marketing. 
The aim of socially responsible brand communication is to make the social, economic, and environmental responsible activities of the brand visible. As we are increasingly talking about the issue of environmental protection or the interests of the whole society in connection with marketing, it is necessary to adapt traditional models of marketing management to this new situation [58]. This also means that the brand has to move from traditional marketing principles to green marketing when creating socially responsible strategies, including communication [59-61].

According to McWilliams and Siegel, socially responsible communication is an important part of brands' success [62]. Diacikova and Dankova dealt with the pros and cons of the green communication of socially responsible brands and their impact on environmentally sensitive consumers [63]. Bratic et al. focused their research on green communication through environmental symbols on packaging and its perception by consumers [64]. Morsing and Schultz emphasized the impact of stakeholders in the long-term value creation of socially responsible brands and the necessity of transforming communication from a monologue to dialogue [65]. Luo and Bhattacharya highlighted the appropriate timing of communication strategy of the socially responsible brand and how it affects brand loyalty, brand reputation, and increasing its value [66]. Bailey et al. reported on three scientific studies focused on relationships between consumers' green behavior as well as their green values and the brand's green communication. They found q significant impact of brands' green communication on consumer behavior in the field of green consumption [67].

It follows from the above mentione, that, although green marketing is generally perceived as the promotion or visibility of brands and products with environmental characteristics, it covers a much wider range of activities, such as ideas, methods, and processes that enable the fulfilment of the brand's environmentally oriented objectives. The necessity for the efficient communication of the socially responsible brand is customizing the content and form of green marketing to the individual target groups.

\subsection{Results of Questionnaire Survey Focused on the Perception of the Green Marketing as a Part of the Socially} Responsible Brand's Communication from the Aspect of Generational Stratification

As previously mentioned, the questionnaire consists of three parts. The first part covered the general socio-demographic profile of respondents: sex and membership of a consumer generation. The second part was focused on the environmental behavior of respondents. We asked respondents if they are active in environmental protection and the level of particular activities they carry out in this field. The last part dealt with the perception of green marketing as a part of the socially responsible brand's communication. We asked respondents if they agree with the statement that brands' usage of green marketing principles is an important factor in purchasing decisions, and also if they prefer a brand that behaves ecologically when making purchasing decisions. We determined if they consider the application of green marketing as a part of the socially responsible brand's communication to be a factor in increasing brand value or not. We also examined, if respondents buy green products, the periodicity of the purchasing and the type of green products they used to buy most often.

From the total number of respondents in the sample set (2035), $1215(60 \%)$ were female and 820 $(40 \%)$ male. On the basis of consumer generation classification, $372(18 \%)$ respondents were Baby Boomers; 592 (29\%) were Generation X; 723 (36\%) were Millennials, and 348 (17\%) were Post-Millennials.

$55 \%$ respondents are active in environmental protection, mainly Millennials (76\%) as well as Post-Millennials (69\%), 43\% Generation X, and only 21\% of Baby Boomers. Regardless of age, most respondents focus on waste recycling $(61 \%)$, reducing electricity, water, and gas consumption $(49 \%)$, environmentally friendly transportation (35\%), and buying organic products (29\%).

The results of the questionnaire survey show that when making purchasing decisions, $51 \%$ of Slovak consumers prefer brands that behave ecologically (applying the principles of green marketing), especially Millennials (69\%) and Post-Millennials (58\%).

Up to $51 \%$ respondents claim that application of green marketing as a part of the socially responsible brand's communication is a factor in increasing brand value ( $70 \%$ of Post-Millennials, 
$60 \%$ of Millennials, $40 \%$ of Generation X, and only $17 \%$ of Baby Boomers). Contrarily, up to $62 \%$ of Baby Boomers and only $10 \%$ of Millennials, as well as $16 \%$ of Post-Millennials, do not agree with this statement.

The survey also addressed the question to respondents of how often and what type of green products they buy. From the results it is clear that those who most often (minimally once a week) buy green product are Millennials (65\%), followed by Post-Millennials (52\%) and Generation X (34\%). Baby Boomers buy green products only occasionally (81\%). All respondents buy mainly organic food, cosmetics, drugstore goods, and cloths.

\subsection{Verification of Statistical Hypotheses}

To verify the statistical hypotheses $1-5$, we used the method testing a single proportion. Results of verification these statistical hypotheses are shown in Table 2.

Table 2. Verification of statistical hypotheses.

\begin{tabular}{|c|c|c|c|c|c|}
\hline $\begin{array}{l}\text { Calculation of the } \\
\text { Sample Proportion: } \\
\qquad p=\frac{m}{n}\end{array}$ & $\begin{array}{l}\text { Satisfaction of the } \\
\quad \text { Condition: } \\
n \times \pi_{0} \times\left(1-\pi_{0}\right)>5\end{array}$ & Test Criteria & Critical Field & Inequality & $\begin{array}{l}\text { Acceptance } \\
\text { or Rejection of the } \\
\text { Hypothesis }\end{array}$ \\
\hline
\end{tabular}

$\mathrm{H}_{0}$ : When making purchasing decisions, $50 \%$ of Slovak consumers prefer a brand that behaves ecologically (applies the principles of green marketing).

$\mathrm{H}_{1}$ : When making purchasing decisions, less than 50\% of Slovak consumers prefer a brand that behaves ecologically (applies the

\begin{tabular}{cccccc}
\multicolumn{5}{c}{ principles of green marketing). } \\
\hline$p=0.51$ & $508.75>5$ & 0.9022 & -1.6449 & $0.9022<-1.6449$ & $\mathrm{H}_{0}$ accepted \\
\hline
\end{tabular}

$\mathrm{H}_{0}: 50 \%$ Baby Boomers consider the application of green marketing as a part of the socially responsible brand's communication to be a factor in increasing brand value.

$\mathrm{H}_{1}$ : More than $50 \%$ Baby Boomers consider the application of green marketing as a part of the socially responsible brand's communication to be a factor in increasing brand value.

\begin{tabular}{cccccc}
\hline$p=0.17$ & $50.75>5$ & -29.7732 & 1.6449 & $-29.7732>1.6449$ & $\mathrm{H}_{0}$ accepted \\
\hline & Hypothesis 3: & &
\end{tabular}

$\mathrm{H}_{0}: 50 \%$ of consumers in Generation X consider the application of green marketing as a part of the socially responsible brand's communication to be a factor in increasing brand value.

$\mathrm{H}_{1}$ : More than $50 \%$ of consumers in Generation X consider the application of green marketing as a part of the socially responsible brand's communication to be a factor in increasing brand value.

\begin{tabular}{cccccc}
\hline$p=0.4$ & $508.75>5$ & -9.0222 & 1.6449 & $-9.0222>1.6449$ & $\mathrm{H}_{0}$ accepted \\
\hline & Hypothesis $4:$ &
\end{tabular}

$\mathrm{H}_{0}: 50 \%$ of Millennials consider the application of green marketing as a part of the socially responsible brand's communication to be a factor in increasing brand value.

$\mathrm{H}_{1}$ : More than $50 \%$ of Millennials consider the application of green marketing as a part of the socially responsible brand's communication to be a factor in increasing brand value.

\begin{tabular}{cccccc}
\hline$p=0.6$ & $508.75>5$ & 9.0222 & 1.6449 & $9.0222>1.6449$ & $\mathrm{H}_{0}$ rejected \\
\hline \multicolumn{6}{c}{ Hypothesis $5:$}
\end{tabular}

$\mathrm{H}_{0}: 50 \%$ of Post-Millennials consider the application of green marketing as a part of the socially responsible brand's communication to be a factor in increasing brand value.

$\mathrm{H}_{1}$ : More than $50 \%$ of Post-Millennials consider the application of green marketing as a part of the socially responsible brand's communication to be a factor in increasing brand value.

$\begin{array}{llllll}p=0.7 & 508.75>5 & 18.0444 & 1.6449 & 18.0444>1.6449 & \mathrm{H}_{0} \text { rejected }\end{array}$

Significance level $\alpha$ was determined at 0.05 . The test criteria were calculated according to:

$$
T=\frac{p-\pi_{0}}{\sqrt{\frac{\pi_{0^{*}\left(1-\pi_{0}\right)}}{n}}}
$$

By using the tables of the normalized normal distribution, we find the critical value for the left-tailed test (2) in the case of hypothesis 1 , and right-tailed test (3) for hypothesis 2-5.

$$
\begin{gathered}
T<-z_{2 \alpha} \\
T>z_{2 \alpha}
\end{gathered}
$$


Table 2 shows that in hypotheses 1-3, the inequality does not apply, so we do not reject the hypothesis $\mathrm{H}_{0}$, we accept it. In the case of hypotheses 4 and 5 , the inequality applies, so we reject the hypothesis $\mathrm{H}_{0}$, i.e., accept the alternative hypothesis $\mathrm{H}_{1}$.

Furthermore, we verify the statistical hypothesis 6 by using Pearson's Chi-square test of independence to determine whether there is a statistically significant relationship between the age of Slovak consumers and their perception of the brand's usage of green marketing principles as an important factor in purchasing decisions.

Hypothesis 6

$\mathrm{H}_{0}$ : There is no statistically significant dependence between the age of Slovak consumers (membership of a generational cohort) and their perception of the brand's usage of green marketing principles as an important factor in purchasing decisions.

$\mathrm{H}_{1}$ : There is statistically significant dependence between the age of Slovak consumers (membership of a generational cohort) and their perception of the brand's usage of green marketing principles as an important factor in purchasing decisions.

For the purpose of determining the dependence, we made a contingency table, where the frequencies are arranged depending on both characters (see Table 3).

Table 3. Contingency table.

\begin{tabular}{ccccccc}
\hline \multirow{2}{*}{ Generation } & \multicolumn{5}{c}{ Brand's Usage of Green Marketing Principles is an Important Factor in } \\
Purchasing Decisions & \multirow{2}{*}{ Sum } \\
\cline { 2 - 6 } & Strongly Agree & Agree & I Don't Know & Disagree & Strongly Disagree & \\
\hline Post-Millennials & 125 & 117 & 52 & 28 & 26 & 348 \\
\hline Millennials & 248 & 184 & 47 & 184 & 60 & 723 \\
\hline Generation X & 84 & 154 & 76 & 205 & 73 & 592 \\
\hline Baby Boomers & 55 & 71 & 14 & 128 & 104 & 372 \\
\hline Sum & 512 & 526 & 189 & 545 & 263 & 2035 \\
\hline
\end{tabular}

The condition has to apply that at least $80 \%$ of the theoretical numbers are greater than 5 and at the same time any frequency cannot be zero, which is met in our case.

Significance level $\alpha$ was determined at 0.05 . The results of the statistical hypothesis testing are shown in Table 4.

Table 4. Chi-Square Tests.

\begin{tabular}{cccc}
\hline & Value & df & Asymptotic Significance (2-Sided) \\
\hline Pearson Chi-Square & $290.279^{\alpha}$ & 12 & 0.000 \\
\hline Likelihood Ratio & 297.974 & 12 & 0.000 \\
\hline N of Valid Cases & 2035 & & \\
\hline
\end{tabular}

Finally, we measured the intensity of the association dependence between the variables by the Cramer's V (Table 5).

Table 5. Symmetric Measures.

\begin{tabular}{cccc}
\hline & & Value & Approximate Significance \\
\hline \multirow{2}{*}{ Nominal by Nominal } & Phi & 0.378 & 0.000 \\
& Cramer's V & 0.218 & 0.000 \\
\hline \multicolumn{2}{c}{ N of Valid Cases } & 2035 & \\
\hline
\end{tabular}


Based on the comparison of the significance level with the p-value (asymptotic significance), we reject the hypothesis $\mathrm{H}_{0}$ and accept the alternative hypothesis $\mathrm{H}_{1}$, i.e., there is a statistically significant relationship between the variables examined (the age of Slovak consumers and their perception of the brand's usage of green marketing principles as an important factor in purchasing decisions). The intensity of the dependence of the variables according to Cramer's V (0.218) indicates a low dependency. Due to the existence of dependence between the variables, it is justified to examine the internal structure of the contingency table by the correspondence analysis. The results are shown in Figure 4.

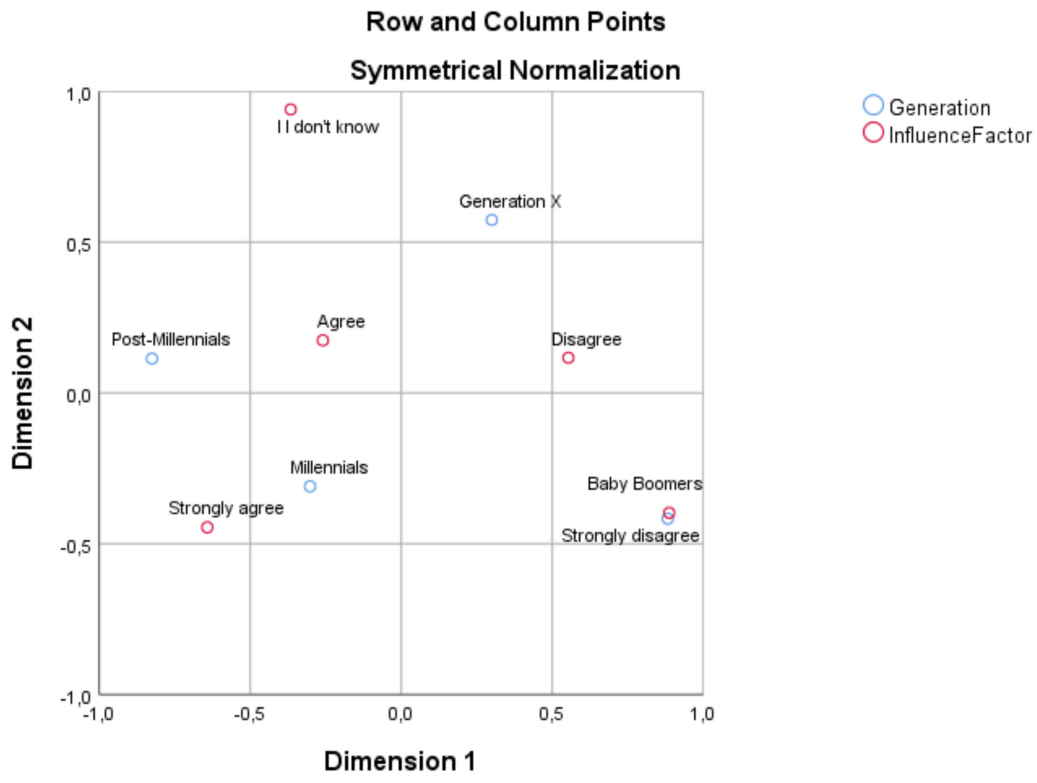

Figure 4. Correspondence map.

The position of the line and column categories in the correspondence map indicates the relationship between categories, i.e., which categories are corresponding to each other. Thus, the results of the correspondence analysis can be interpreted as follows. Millennials strongly agree with the statement that brand's usage of green marketing principles is an important factor in purchasing decisions. This fact represents an important result of the correspondence analysis. In contrast, Baby Boomers mainly strongly disagree with the statement. Post-Millennials are in the range between agreement with the claim and the option "I don't know", because these two options are in a common quadrant of the map. Generation $X$ is specific, so it does not show common characteristics in terms of agreement with the statement. However, we can say they are closest to the option that they disagree with the statement.

\section{Discussion}

Based on the mentioned above, it is obvious that different target groups may have different attitudes and behavior, including environmental awareness. The majority of previous research focused on generational stratification suggests that members of a consumer generation have mostly the same environmental behavior, and this fact influences their relationship with socially responsible brands $[37-47,68,69]$. Therefore, it is necessary to focus the communication on consumer generations with positive environmental awareness that represents the target groups of socially responsible brands. An appropriate and well-targeted green marketing strategy as a part of socially responsible communication can thus positively influence the attitudes and buying behavior of individual consumer generations.

Recently, there were several opinions from authors and researchers who do not agree with the concept of generational stratification [25]. As their main reasons, they mention stereotypes, cyclicality, the absence of lifestyle specifics, and the disputed universal applicability [70-75]. According to Kriegel, 
the approach to people with regard to the identified generational differences assumes that people are more influenced by cultural events than personal experiences or conditions. At the same time, it assumes that predefined generational templates suppress individualism and do not take into account the existence of generational variability [70]. Some critics add that the tendency to create stereotypes is misleading, as consumer behavior is not universal and predictable in the context of generational stratification, and that the main reason for subjectivism in consumer behavior is human experience [71,72]. Cyclicality as one of the arguments of the critique of generational theory is related to the assumption that certain attitudes, opinions or needs are typical for people at a certain stage of life, regardless of the generation [73]. The absence of lifestyle specifics is characteristic mainly for the generation of Millennials, because belonging to the segment of millennials is not defined mainly by age, but such external factors as socio-economic maturity and regional specifics also play an important role in this process [74]. The disputed universal applicability is related to the fact that the traditional concept of generational stratification originated in the US. Despite the fact that globalization has led to a radical increase in the degree of interdependence of national economies, it is necessary to accept the regional socio-cultural specifics of the market [75].

However, based on our survey results, it is clear that members of individual generations have mainly the same environmental awareness and attitude to the socially responsible brands. Up to half of Slovak consumers (mainly Millennials and Post-Millennials) prefer and buy products of the brand that behaves ecologically, i.e., applies the principles of green marketing. Similarly, both mentioned generations mainly think that the application of green marketing as a part of socially responsible brands' communication is a factor in increasing brand value. Thus, we can claim that Millennials and Post-Millennials represents the target group of socially responsible brand in Slovak conditions.

Millennials represent the largest adult generation, the most consumer-oriented and with a major impact on the economy. Members of this generation declare willingness to contribute to socially responsible activities, although sometimes only in a secondary way. In any case, they are satisfied when they know that they are helpful to sustainability. Thus, they represent the target segment, as they prefer socially responsible brands and products. The green marketing strategy of socially responsible brands should follow the environmental preferences of Millennials, such as:

- A focus on innovative products,

- A preference of environmental properties of products,

- A willingness to pay more for a higher-quality product, such as a product with environmental properties,

- A medium recycling rate, saving energy resources,

- A willingness to participate in environmental projects,

- A positive relationship and preference for digital media (internet advertising, websites, email marketing, social networks, blogs, and podcasts) as a socially responsible communication tool.

Post-Millennials also represent the target segment, although they are much smaller and thus have less influence, but an even greater perspective for the future. They are considered to be the first globally thinking generation, which is not indifferent to the issue of environmental protection or climate change. As this is a generation with above-average digital skills and orientation, it is appropriate to focus socially responsible communication through digital media. The green marketing strategy of the socially responsible brand should be adapted to their environmental behavior, which includes:

- brand orientation, strong brand loyalty,

- a preference for online product ordering,

- an interest in the environmental properties of products,

- a lower willingness to pay more for a product with environmental characteristics,

- interest and knowledge about the environment,

- fear of environmental pollution,

- a medium recycling rate, 
- a willingness to participate in environmental projects,

- preferring communication via digital media (social networks, blogs and podcasts, discussion forums, mobile applications, influencer marketing, etc.).

The crucial limitation in our research is its territorial validity. The results of questionnaire surveys and hypotheses verification are fully valid only in the case of Slovak consumer generations. This means that it is not possible to apply these claims and recommendations to foreign effective practice of green marketing as a part of socially responsible brands' communication. However, this limitation can be removed if the research is tailored to consumers of the selected country, and national and cultural specifics will be taken into account. In this way, results of the research could be considered as relevant, and they could be subject to subsequent verification in the foreign as well as in the international environment.

\section{Conclusions}

At present, there is a growing interest in socially responsible brands and environmentally friendly products. This naturally leads to growing interest in green marketing. Environmental protection is increasingly attracting the public's attention [76]. People are actively trying to reduce the negative impact of their activities on the environment. With the growing interest of consumers in environmental issues, many socially responsible brands are integrating environmental issues into their activities and are changing their business strategies in favour of a greener concept. Thus, brands applying green marketing gain a competitive advantage over those that do not deal with environmental issues. However, the most important thing is to choose an appropriate green marketing strategy as a part of efficient and properly targeted communication of socially responsible activities; thus, the brand may achieve its goals. With the right strategy, the socially responsible brand may gain new business opportunities and competitive advantages, but also make a significant contribution to protecting the environment and protecting the world from environmental disasters. Therefore, the most important benefits of green marketing as a part of the socially responsible brand's communication focused on individual consumer generations include gaining competitive advantage, increasing the brand value, improving brand loyalty, and increasing the attractiveness for investors.

The outcomes of the research provide the overview of the environmental awareness and attitude to socially responsible brands from the viewpoint of individual consumer generations in Slovak conditions, which can be considered as a main theoretical benefit of the article. It also provides space for further discussions on specific activities of green marketing in relation to generational cohorts. It is obvious that Millennials and Post-Millennials represent the target group of the socially responsible brand, because they prefer and buy products of the socially responsible brand. Additionally, both mentioned generations consider the application of green marketing as a part of the socially responsible brand's communication as a factor in increasing brand value. Thus, the survey results can have a significant application in practice, especially in predicting purchasing behavior based on attitudes and ecological behavior of target segments, but also appropriate managing and targeting of socially responsible communication based on generational stratification.

Based on this, the main managerial recommendation consists of the targeting in the mentioned two generations within green marketing as a part of socially responsible brands' communication in Slovak conditions. The next reason is that, in addition to changes in consumption preferences, in the case of Millennials and Post-Millennials, there are positive changes in favor of the overall greening of lifestyles. This includes customizing the communication according to preferences of the target group to gain their attention and loyalty.

It follows from the above thst the issue of green marketing as a part of the socially responsible brand's communication from the aspect of generational stratification has great potential for further research. It would be appropriate to examine and compare the impact of green marketing of socially responsible brands on Millennials and Post-Millennials in particular fields. 
However, there is gradually emerging the youngest target group, so-called Generation Alpha (born 2009-present), which is living in symbiosis with information and communication technologies, and according to several experts, in the future it will represent the richest, most educated, most numerous, and also the longest living generation. Thus, it may be interesting to focus future research to determine the perception of green marketing and the environmental behavior of Generation Alpha.

Author Contributions: Conceptualization: M.N. and L.G.; methodology: M.N., L.G. and J.M.; software: M.N. and L.G.; validation: L.G. and J.M.; formal analysis: M.N. and J.M.; investigation: M.N. and L.G.; resources: M.N. and L.G.; writing—original draft preparation: M.N. and L.G.; writing—review and editing: L.G. and J.M.; visualization: M.N.; supervision: M.N., L.G. and J.M. All authors have read and agreed to the published version of the manuscript.

Funding: This research was funded by the Slovak Research and Development Agency grant number APVV-15-0505: Integrated Model of Management Support for Building and Managing the Brand Value in the Specific Conditions of the Slovak Republic.

Acknowledgments: This article has benefited from constructive feedback on earlier drafts by the anonymous reviewers, the editors and the chief editor.

Conflicts of Interest: The authors declare no conflict of interest. The funders had no role in the design of the study; in the collection, analyses or interpretation of data; in the writing of the manuscript or in the decision to publish the results.

\section{References}

1. Gregova, E.; Kramarova, K.; Dengov, V.V. Signifinance of the Corporate Social Responsibility at National and International Level. In Proceedings of the International Conference on Information and Business Management, Hong Kong, China, 3-4 September 2016; pp. 9-15.

2. Moravcikova, D.; Krizanova, A.; Kliestikova, J.; Rypakova, M. Green Marketing as the Source of the Competitive Advantage of the Business. Sustainability 2017, 9, 2218. [CrossRef]

3. Sroka, W.; Szanto, R. Corporate Social Responsibility and Business Ethics in Controversial Sectors: Analysis of Research Results. J. Entrep. Manag. Innov. 2018, 14, 111-126. [CrossRef]

4. Stonkute, E.; Vveinhardt, J.; Sroka, W. Training the CSR Sensitive Mind-Set: The Integration of CSR into the Training of Business Administration Professionals. Sustainability 2018, 10, 754. [CrossRef]

5. Prosenak, D.; Mulej, M.; Snoj, B. A requisitely holistic approach to marketing in terms of social well-being. Kybernetes 2008, 37, 1508-1529. [CrossRef]

6. Polonsky, J. An Introduction to Green Marketing. Electron. Green J. 1994, 1, 1-10. [CrossRef]

7. Henion, K.E.; Kinnear, T.C. Ecological Marketing; American Marketing Association: Chicago, IL, USA, 1976; pp. 1-2.

8. Menon, A.; Menon, A. Enviropreneurial marketing strategy: The emergence of corporate environmentalism as market strategy. J. Mark. 1997, 61, 51-67. [CrossRef]

9. McDaniel, S.W.; Rylander, D.H. Strategic green marketing. J. Consum. Mark. 1993, 10, 4-10. [CrossRef]

10. Baker, M.J. The Marketing Book, 5th ed.; Butterworth-Heinemann: Burlington, MA, USA, 2003; p. 727.

11. Juraskova, O.; Hornak, P. Velký Slovnik Marketingových Komunikací; Grada Publishing: Praha, Czech Republic, 2012 ; p. 82.

12. White, K.; MacDonnell, R.; Dahl, D.W. It's the mind-set that matters: The role of construal level and message framing in influencing consumer efficacy and conservation behaviors. J. Mark. Res. 2011, 48, 472-485. [CrossRef]

13. American Marketing Association. Available online: http://www.marketingpower.com/_layouts/dictionary.aspx (accessed on 25 February 2020).

14. Grant, J. The Green Marketing Manifesto; John Wiley \& Sons: Chichester, West Sussex, UK, 2007; 320p.

15. Kicova, E.; Krizanova, A. Building a sustainable brand. In Springer Proceedings in Business and Economics: Advances in Applied Economic Research; Tsounis, N., Vlachvei, A., Eds.; Springer International Publishing: Cham, Switzerland, 2017; pp. 367-379. 
16. Kliestikova, J.; Kovacova, M.; Krizanova, A. Brand value sources: Case study of bank brands in Slovak republic. In Proceedings of the 39th International Scientific Conference Economic and Social Development-Sustainability from an Economic and Social perspective, Lisbon, Portugal, 29-30 April 2019; pp. 361-368.

17. Stuchly, J.; Jambal, T.; Lizbetinova, L. Loyalty Programs and Customer Preferences. In Proceedings of the 32nd Conference of the International Business Information Management Association-Vision 2020: Sustainable Economic Development and Application of Innovation Management, Seville, Spain, 15-16 November 2018; pp. 8321-8328.

18. Howe, N.; Strauss, W. The Next 20 Years: How Customer and Workforce Attitudes Will Evolve. Harv. Bus. Rev. 2007, 85, 41-52.

19. Tolbize, A. Generational Differences in the Workplace; University of Minnesota: Minneapolis, MN, USA, 2008 ; p. 25.

20. Troll, L.E. Issues in the study of generations. Aging Hum. Dev. 1970, 1, 199-218. [CrossRef]

21. Nazareth, L. The Leisure Economy: How Changing Demographics, Economics, and Generational Attitudes Will Reshape Our Lives and Our Industries; John Wiley \& Sons: Toronto, ON, Canada, 2007; p. 288.

22. Taylor, P. The Next America: Boomers, Millennials, and the Looming Generational Showdown; Hachette UK: London, UK, 2016; p. 384.

23. Kim, N.; Srivastava, R.K.; Han, J.K. Consumer decision-making in a multi-generational choice set context. J. Bus. Res. 2001, 53, 123-136. [CrossRef]

24. Keyser, H. How Do Generations Get Their Names? Available online: http://mentalfloss.com/article/59963/ how-do-generations-get-their-names (accessed on 20 February 2020).

25. Reeves, T.C.; Oh, E. Generation Differences. In Handbook of Research on Educational Communications and Technology; Lawrence Erlbaum Associates: New York, NY, USA, 2008; pp. 295-303.

26. Raphaelson, S. From GIs to Gen Z (Or Is It iGen?): How Generations Get Nicknames. Available online: https://www.npr.org/2014/10/06/349316543/don-t-label-me-origins-of-generational-names-and-why-weuse-them? $\mathrm{t}=1529763974286$ (accessed on 20 February 2020).

27. WJSchroer. Generations X, Y, Z and the Others. Available online: http://socialmarketing.org/archives/ generations-xy-z-and-the-others/ (accessed on 20 February 2020).

28. Bromwich, J.E. Tell Us What to Call the Generation after Millennials (Please). Available online: https: //www.nytimes.com/2018/01/23/style/generationnames.html?action=click\&module=RelatedCoverage\& pgtype $=$ Article\&region $=$ Footer (accessed on 21 February 2020).

29. Bromwich, J.E. We Asked Generation Z to Pick a Name. It Wasn't Generation, Z. Available online: https://www.nytimes.com/2018/01/31/style/generation-z-name.html (accessed on 21 February 2020).

30. Loria, K.; Lee, S. Here's Which Generation You're Part of Based on Your Birth Year-and Why Those Distinctions Exist. Available online: http://www.businessinsider.com/generation-you-are-in-by-birth-yearmillennial-gen-x-baby-boomer-2018-3 (accessed on 23 February 2020).

31. Kim, S. Managing millennials' personal use of technology at work. Bus. Horiz. 2018, 61, 261-270. [CrossRef]

32. Au-Yong-Oliveira, M.; Goncalves, R.; Martins, J.; Branco, F. The social impact of technology on millennials and consequences for higher education and leadership. Telemat. Inform. 2018, 35, 954-963. [CrossRef]

33. Chicca, J.; Shellenbarger, T. Connecting with Generation Z: Approaches in Nursing Education. Teach. Learn. Nurs. 2018, 13, 180-184. [CrossRef]

34. McCrindle, M. The ABC of XYZ: Understanding the Global Generations; McCrindle Research: Bella Vista, AR, USA, 2014; p. 288.

35. Fry, R. Millennials are the Largest Generation in the U.S. Labor Force. Available online: http://www.pewresearch. org/fact-tank/2018/04/11/millennials-largest-generation-us-labor-force/ (accessed on 1 March 2020).

36. Dimock, M. Defining Generations: Where Millennials End and Post-Millennials Begin. Available online: http://www.pewresearch.org/fact-tank/2018/03/01/defining-generations-where-millennials-end-and-postmillennials-begin/ (accessed on 1 March 2020).

37. Arıker, Ç.; Toksoy, A. Generation Z and CSR: Antecedents of purchasing intention of university students. KAUJEASF 2017, 8, 483-502. [CrossRef]

38. Van den Bergh, J.; Behrer, M. How Cool Brands Stay Hot: Branding to Generations Y and Z; Kogan Page: London, UK, 2016; p. 312.

39. Nielsen. The Sustainability Imperative. Available online: https://www.nielsen.com/us/en/insights/report/ 2015/the-sustainability-imperative-2/\# (accessed on 29 May 2020). 
40. Sourcing Journal. What Millennials and Gen Z Think of Your Brand's CSR Efforts, and What You Can Do about It. Available online: https://sourcingjournal.com/topics/sustainability/qima-social-environmentalissues-165663/ (accessed on 29 May 2020).

41. Lumesse. Corporate Social Responsibility Is a Key in Attracting Millennials. Available online: https://www.greenbeanrpo.com/wp-content/uploads/2018/02/corporate_social_responsiblity_attracting_ millenials_white_paper.pdf (accessed on 29 May 2020).

42. Lazarevic, V. Encouraging brand loyalty in fickle generation Y consumers. Young Consum. 2012, 13, 45-61. [CrossRef]

43. Vilela, A.M.; Nelson, M.R. Testing the selectivity hypothesis in cause-related marketing among generation y: [When] does gender gatter for short- and long-term persuasion? J. Mark. Commun. 2016, 22, 1-18. [CrossRef]

44. Nga, J.K.H.; Soo, N.W.M. A study on the factors influencing the perception of ethical branding among generation y consumers in Malaysia. AFBE J. 2013, 6, 40-62.

45. Yoon, J.M.; Littrel, M.A.; Niehm, L. Young female consumers' intentions toward fair trade consumption. Int. J. Retail Distrib. Manag. 2012, 40, 41-63.

46. Kim, H.S. A reputational approach examining publics' attributions on corporate social responsibility. Asian J. Commun. 2011, 21, 84-101. [CrossRef]

47. Gao, Y. Doing well by doing good, or doing ill by doing good? An integrated model of consumer responses to corporate disaster relief giving. Afr. J. Bus. Manag. 2012, 6, 9569-9576. [CrossRef]

48. Kliestikova, J.; Janoskova, K. Branding with understanding: How national profile of consumer influences brand value perception. Mark. Manag. Innov. 2017, 3, 149-157. [CrossRef]

49. Tague-Sutcliffe, J. An introduction to informetrics. Inf. Process. Manag. 1992, 28, 1-3. [CrossRef]

50. De Bellis, N. Bibliometrics and Citation Analysis: From the Science Citation Index to Cybermetrics; The Scarecrow Press: Lanham, MD, USA, 2009; p. 450.

51. Macfie, B.P.; Nufrio, P.M. Applied Statistics for Public Policy; M. E. Sharpe: New York, NY, USA, $2006 ;$ p. 554.

52. Rimarcik, M. Štatistika Pre Prax; Marian Rimarcik: Kosice, Slovakia, 2007; p. 200.

53. Ruxton, G.D.; Neuhauser, M. When should we use one-tailed hypothesis testing? Methods Ecol. Evol. 2010, 1, 114-117. [CrossRef]

54. Lombardi, C.M.; Hurlbert, S.H. Misprescription and misuse of one-tailed tests. Aust. Ecol. 2009, 34, 447-468. [CrossRef]

55. McHugh, M.L. The Chi-square test of independence. Biochem. Med. 2013, 23, 143-149. [CrossRef]

56. Sourial, N.; Wolfson, C.; Zhu, B.; Quail, J.; Fletcher, J.; Karunananthan, S.; Bandeen-Roche, K.; Beland, F.; Bergman, H. Correspondence analysis is a useful tool to uncover the relationships among categorical variables. J. Clin. Epidemiol. 2010, 63, 638-646. [CrossRef]

57. Kral, P. Viacrozmerné Štatistické Metódy So Zameraním Na Riešenie Problémov Ekonomickej Praxe; Matej Bel University: Banska Bystrica, Slovakia, 2019; p. 175.

58. Hitka, M.; Pajtinkova-Bartakova, G.; Lorincova, S.; Palus, H.; Pinak, A.; Lipoldova, M.; Krahulcova, M.; Slastanova, N.; Gubiniova, K.; Klaric, K. Sustainability in marketing through customer relationship management in a telecommunication company. Mark. Manag. Innov. 2019, 4, 194-215. [CrossRef]

59. Kliestikova, J.; Kovacova, M.; Krizanova, A.; Durana, P.; Nica, E. Quo Vadis brand loyalty? Comparative study of perceived brand value sources. Pol. J. Manag. Stud. 2019, 19, 190-203. [CrossRef]

60. Valjaskova, V.; Kliestikova, J. The main aspects of brand portfolio management. In Proceedings of the 8th International Scientific Symposium on Economy of eastern Croatia-Vision and Growth, Osijek, Croatia, 30-31 May 2019; pp. 1253-1260.

61. Lizbetinova, L.; Starchon, P.; Lorincova, S.; Weberova, D.; Prusa, P. Application of Cluster Analysis in Marketing Communications in Small and Medium-Sized Enterprises: An Empirical Study in the Slovak Republic. Sustainability 2019, 11, 2302. [CrossRef]

62. McWilliams, A.; Siegel, D. Corporate Social Responsibility: A Theory of the Firm Perspective. Acad. Manag. Rev. 2001, 26, 117-127. [CrossRef]

63. Diacikova, A.; Dankova, A. Green Marketing Communication. In Proceedings of the 2nd International Scientific Conference of the Poprad Economic and Management Forum, Poprad, Slovakia, 17-18 October 2019; pp. 83-89. 
64. Bratic, D.; Palic, M.; Lisanin, M.T.; Gajdek, D. Green marketing communications in the function of sustainable development. In Proceedings of the 11th Annual Conference of the EuroMed Academy of Business—Research Advancements in National and Global Business Theory and Practice, Valletta, Malta, 12-14 September 2018; pp. 185-198.

65. Morsing, M.; Schultz, M. Corporate social responsibility communication: Stakeholder information, response and involvement strategies. Bus. Ethics Eur. Rev. 2008, 15, 324-338. [CrossRef]

66. Luo, X.; Bhattacharya, C.B. The Debate over Doing Good: Corporate Social Performance, Strategic Marketing Levers, and Firm-Idiosyncratic Risk. J. Mark. 2009, 73, 198-213. [CrossRef]

67. Bailey, A.A.; Mishra, A.S.; Tiamiyu, M.F. Application of GREEN scale to understanding US consumer response to green marketing communications. Psychol. Mark. 2018, 35, 863-875. [CrossRef]

68. Mitellman, R. Green Consumer Behavior in Emerging Markets: A Review of Research. In Proceedings of the Annual Marketing Division Conference of the Administrative Sciences Association of Canada, St. John's, NL, Canada, 8-11 June 2012; pp. 392-441.

69. Musova, Z. Implementation of modern marketing concepts in the Slovak Republic. In Development of Marketing Theory and Practice-Scientific Monograph Proceedings; EDIS: Zilina, Slovakia, 2010; pp. 47-52.

70. Kriegel, J. Why Generational Theory Makes No Sense. Available online: https://www.forbes.com/sites/oracle/ 2015/09/29/why-generational-theory-makes-no-sense/\#1df55c4c8eaa (accessed on 10 March 2020).

71. Onion, R. Generational Labels Are Lazy, Useless, and Just Plain Wrong. Available online: https://aeon.co/ essays/generational-labels-are-lazy-useless-and-just-plain-wrong (accessed on 10 March 2020).

72. Quiggin, J. 'Millennial' Means Nothing. Available online: https://search-proquest-com.zdroje.vse.cz/docview/ 2011045515/fulltext/8A467EB607A34688PQ/3?accountid=17203 (accessed on 10 March 2020).

73. Scandura, T.; Mourino, E. Leading Diversity in the 21st Century; Information Age Publishing: Charlotte, NC, USA, 2017; p. 222.

74. Median. MML-TGI: Analýza Mileniálů. Available online: http://showme.median.cz/mml-milenialove/ (accessed on 10 March 2020).

75. Chlebecek, T.; Konecny, M.; Stojanov, R.; Volfova, A.; Horky, O.; Zacalova, P.J. Globalizace. Available online: http://www.rozvojovka.cz/globalizace (accessed on 10 March 2020).

76. Skrucany, T.; Kendra, M.; Jurkovic, M.; Kalina, T. Environmental Comparision of Different Transport Modes. NASE MORE Znan. Strucni Cas. More Pomor. 2018, 65, 192-196. 